\title{
Analysis of the Carrying Capacity and the Total Maximum Daily Loads of the Karang Mumus Sub-watershed in Samarinda City Using the WASP Method
}

\author{
Achmad Diansyukma ${ }^{1,}$, Sri Puji Saraswati ${ }^{1}$, Ahmad Tawfiequrrahman Yuliansyah ${ }^{2}$ \\ ${ }^{1}$ Department of Civil and Environmental Engineering, Universitas Gadjah Mada, Yogyakarta, INDONESIA \\ Jalan Grafika No 2, Sekip, 55281 Yogyakarta \\ ${ }^{2}$ Department of Chemical Engineering, Universitas Gadjah Mada, Yogyakarta, INDONESIA \\ Jalan Grafika No 2, Sekip, 55281 Yogyakarta \\ "Corresponding authors: achmad.diansyukma@mail.ugm.ac.id
}

SUBMITTED 4 January 2021 REVISED 9 February 2021 ACCEPTED 21 February 2021

\begin{abstract}
Watershed is a multi-aspect ecological system, which functions as a source of water resources, in order to meet daily needs. It also motivates both economical and life matters, as well as serve as a sanitary channel for the surrounding community. Watershed also generates pollutants, which are known to potentially cause a decrease in river water quality. The degradation of river habitats that are caused by high pollutants penetration into the water body, decreases the capacity to carry out self-purification of toxic loads. The water pollutant loadcarrying capacity is then calculated through various methods, one of which is the use of a computerized numerical modeling simulation called WASP (Water Quality Analysis Simulation Program). This method was developed by the ES-EPA, in order to process TMDLs (Total Maximum Daily Loads) data on river bodies, as well as examine each part of the water quality, based on spatial and temporal inputs. This study was conducted at the Karang Mumus Sub-watershed flowing through the centre of Samarinda City, with aims to determine the pollutants' carrying capacity, existing load, and toxic waste allocation, via the use of the BOD (Biological Oxygen Demand) technique as a parameter of water quality. The calculation was carried out by segmenting the river into five parts, based on the number of districts it passes through, during pollutant loads inventory. The WASP modeling simulation showed that the total pollutant load-carrying capacity of the whole segments was $5,670 \mathrm{~kg} /$ day. It also showed the existing loads of about $3,605 \mathrm{~kg} /$ day, with the margin having the ability to receive pollutants at $2,065 \mathrm{~kg} /$ day. Moreover, the allocation of pollutant loads varies for each segment, with 2, 3, and 4 observed to reduce the pollutant by 390,220 , and $10 \mathrm{~kg} / \mathrm{day}$, respectively. However, segments 1 and 5 were still allowed to receive pollutant loads up to 1,740 and $945 \mathrm{~kg} /$ day, respectively.
\end{abstract}

KEYWORDS: Watershed; Pollutant Load-Carrying Capacity; TMDL; WASP; BOD.

(C) The Author(s) 2021. This article is distributed under a Creative Commons Attribution-ShareAlike 4.0 International license.

\section{INTRODUCTION}

The Karang Mumus Sub-watershed is known to be a tributary of the Mahakam River, which flows through the centre of Samarinda City, crossing 5 districts, namely Samarinda Ilir, Kota, Ulu, and Utara, as well as Sungai Pinang. Astronomically, Samarinda City lies between $117^{\circ} 03^{\prime} 00^{\prime \prime}-$ $117^{\circ} 18^{\prime} 14^{\prime \prime}$ East Longitude and $00^{\circ} 19^{\prime} 02^{\prime \prime}-$ $00^{\circ} 42^{\prime} 34^{\prime \prime}$ South Latitude, with an area of 718 $\mathrm{km}^{2}$, as stated in Government Regulation Number 21 of 1987, concerning the Determination of Regional Municipal Boundaries Level II Samarinda. Based on its topographical characteristics, this city is considered to be lying on a fairly flat slope. A total of $27.39 \%$ and $25.47 \%$ of its area lies on a slope of less than $2 \%$ and $2-15 \%$, respectively. Based on the population growth projections in 2018, Samarinda City is inhabited by 858,080 people, with a growth rate and density of 3.2\% and 1,195 people $/ \mathrm{km}^{2}$, respectively (BPS, 2019).

The surface water resources, especially the river, are found to be managed in units of watersheds (Triatmodjo, 2008). Furthermore, a watershed consist a set of physical, chemical, and biological elements, which are connected by the flow of water. Also, it is often analogous to the terms 'catchment' and 'drainage basin' (Flotemersch et al., 2015). As a multi-aspect ecological system, watershed plays an important role in meeting daily needs, motivating economical and life activities, as well as being a sanitary channel of the surrounding community. Watershed also generates pollutants that potentially cause reductions in river water quality (Asdak, 2010; Djoharam, Riani and Yani, 2018). Morphologically, the Karang Mumus Sub- 
watershed is observed to be narrow and wider at the up and downstream regions, respectively. The upstream region of the river is Benanga Dam, which is a flood control infrastructure in Samarinda City. The land around Benanga Dam is predominantly used for food crop agriculture, by a few farmers. For the small number of settlements and community social activities, this part of the river appears clean, as well as free from dirts. The middle section of the river flows through the centre of Samarinda city, where settlements are getting denser with increasingly diverse socio-economic activities, such as traditional markets, shopping malls, hospitals, hotels, and government offices. Based on the behaviours of people living around the riverbanks, the river begins to become dirty, smelly, and cloudy, as well as contain lots of garbage. These types of behaviour includes the process of bathing, washing, and excreting (MCK). Also, the disposal of wastes into the river contributes to the pollutant loads from the domestic sector (Pramaningsih, Suprayogi and Setyawan Purnama, 2017). The downstream section looks slightly similar to that of the middle, however, it is observed to be cleaner, and affected by the tides from the Mahakam watershed. The results of monitoring conducted by the Environmental Agency (BLH) of Samarinda City in 2014-2019, revealed that the Mumus Sub-watershed was still heavily polluted. This statement was based on the calculation showing that Water Quality Indices (WQIs) in 2014, 2015, and 2017 were at $-117,-37$, and -34 , respectively, via the use of a STORET Method. Also, WQIs in 2018 and 2019 were observed at 10.7 and 11.3, respectively, via the use of a PI method.

Based on BOD (Biological Oxygen Demand) as a parameter, this study aims to identify the carrying capacity and total pollutant load allocation, along $16.6 \mathrm{~km}$ (approximately) of the Karang Mumus Sub-watershed, using the Water Quality Analysis Simulation Program (WASP) software. For a river containing big amount of domestic wastes, BOD should be used as one of the properties to identify water pollution (Wen,
Schoups and Van De Giesen, 2017). This study was reportedly important in assisting the local government to create policies concerning the rehabilitation and revitalization of the Karang Mumus Sub-watershed, in order to avoid pollution loads from exceeding the predetermined quality standards, as well as restoring the river to its normal conditions.

\section{METHODS}

\subsection{Research Framework}

This study was performed based on theoretical aspects, by considering several references from previous research, which involves both actual and model systems. A model system was created through the WASP, in order to predict the water quality that was calibrated by the actual system, in order to obtain representative pollutant loads. Validation and reliability tests were also conducted, after the model was established. However, when the model was rejected based on the test results, recalibration was performed.

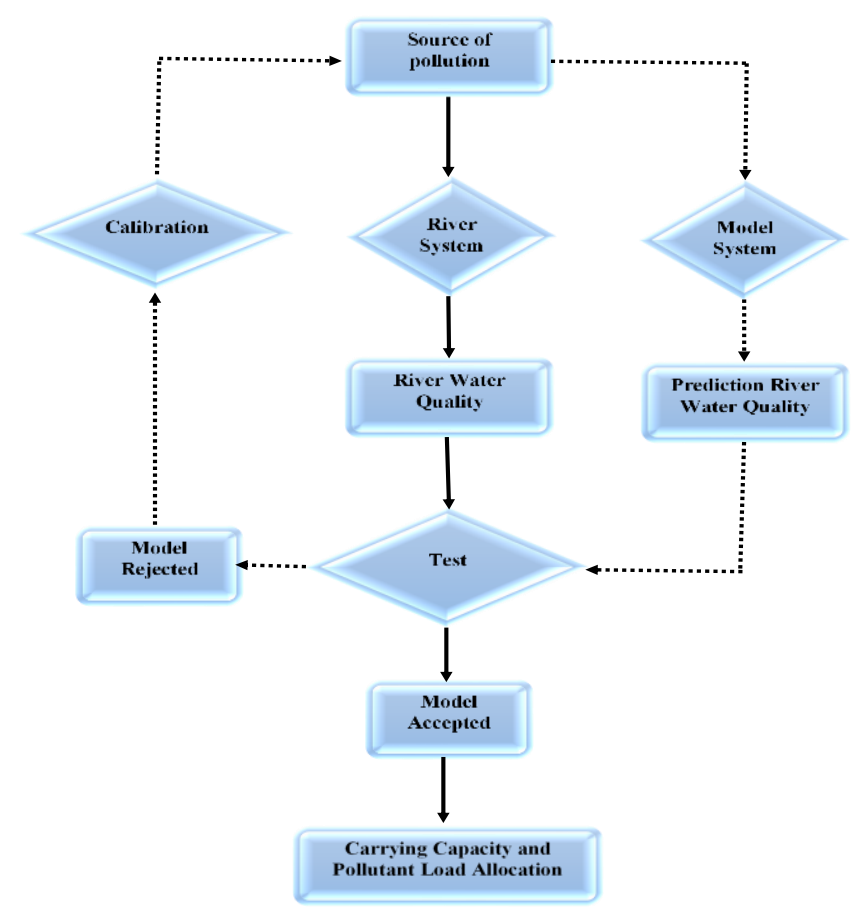

Figure 1. Research Framework.

\subsection{Data Collection}

In this study, data were collected from primary and secondary sources. The primary data were obtained directly from field surveys and observations, compared to those of the 
secondary, which were collected from related parties, such as the Environmental Agency of Samarinda City and River Basin Organization III, as the caretaker of the Karang Mumus Subwatershed. The water quality variable used by BOD relied on data from trusted sources, which belonged to the Environmental Agency of Samarinda, as an official source that had certainly passed the quality assurance, in order for false conclusion to be avoided (Saraswati et al., 2019).

\subsection{Segmentation of River Body}

The study area was divided into several segments, with determination based on variations in pollutant load, morphology of river, and direction of open channel flow. The variation of pollutant load was intended, in order to determine the contribution of the pollutant load for each segment. However, the river morphology affected the flowrate and quality of water, as the direction of open channel flow was carried out in identifying the potential flow channel of nonpoint source pollution.

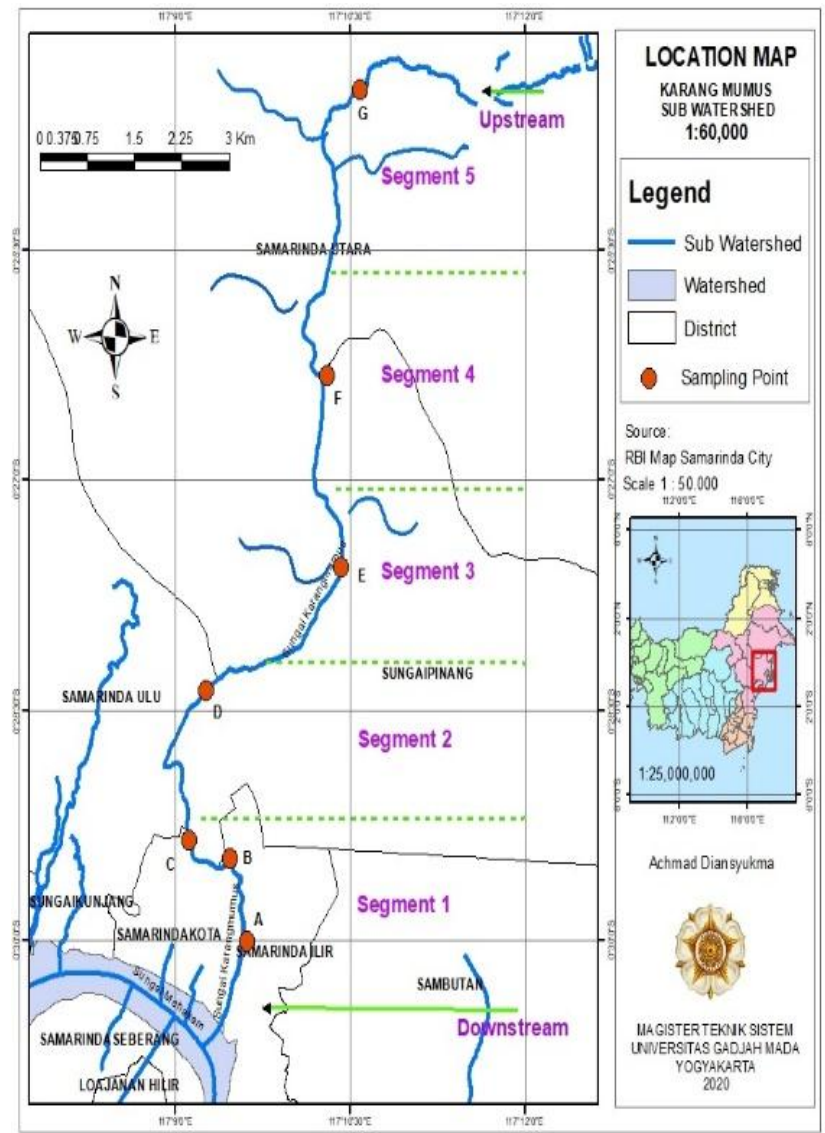

Figure 2. Map of Karang Mumus Sub-watershed
Table 1. Segmentation and Potential of Pollutant Sources

\begin{tabular}{|c|c|c|c|}
\hline Location & $\begin{array}{l}\text { Point } \\
\text { Code }\end{array}$ & Segment & $\begin{array}{l}\text { Potential of } \\
\text { Pollutant Source }\end{array}$ \\
\hline $\begin{array}{l}\text { Sei Dama Bridge } \\
\text { to Perniagaan } \\
\text { Bridge }\end{array}$ & $\mathrm{A}$ & 1 & $\begin{array}{l}\text { Densely Populated } \\
\text { Settlement, } \\
\text { Traditional Market, } \\
\text { Government } \\
\text { Office, Hotel, } \\
\text { Laundry and } \\
\text { Hospital }\end{array}$ \\
\hline $\begin{array}{l}\text { Perniagaan } \\
\text { Bridge to S. } \\
\text { Parman Bridge }\end{array}$ & $\mathrm{D}$ & 2 & $\begin{array}{l}\text { Densely Populated } \\
\text { Settlement, Slums, } \\
\text { Hospital, Hotel, } \\
\text { Laundry and Mall }\end{array}$ \\
\hline $\begin{array}{l}\text { S. Parman } \\
\text { Bridge to } \\
\text { Sempaja River }\end{array}$ & E & 3 & $\begin{array}{l}\text { Modern Housing } \\
\text { Complex, Campus, } \\
\text { Hotel, Laundry }\end{array}$ \\
\hline $\begin{array}{l}\text { Sempaja River to } \\
\text { Mugirejo River }\end{array}$ & $\mathrm{F}$ & 4 & $\begin{array}{l}\text { Public Housing, } \\
\text { Traditional Market }\end{array}$ \\
\hline $\begin{array}{l}\text { Mugirejo River } \\
\text { to Benanga Dam } \\
\text { Bridge }\end{array}$ & G & 5 & $\begin{array}{l}\text { Public Housing, } \\
\text { Agriculture }\end{array}$ \\
\hline
\end{tabular}

\subsection{Pollutant Load Estimation}

Based on water quality, the criticality of the watershed was reduced, by decreasing the penetration of pollutant loads into the river. Also, the amount of pollutant loads reduction was determined by the carrying capacity of the water body (Abdi, Hadi and Widiyastuti, 2011). The carrying capacity and Total Maximum Daily Loads (TMDLs) are defined as the limit of the water resources' ability to receive pollutants, in order to meet the quality requirements and standards for various uses (Hindriani et al., 2013).

The nonpoint source pollution, which was generated by land-used settlements, small industries, livestock, or agriculture was unable to be calculated directly (Wijaya and Juwana, 2018), therefore, requiring an Emission Factor. This was due to the fact that each waste source had an Emission Factor value, which is also known as Pollutant Load Unit (Iskandar, 2007). The Emission Factor used in this research was for BOD, due to its relationship with the degradation of organic wastes. BOD is defined as the amount of oxygen required by microorganisms present in environmental water, in order to break down or degrade organic waste materials (Wardhana, 2004). A simplified illustration of the 
relationship between BOD and quantity of pollution, depicted that the initial concentration of organic matters (easily oxidized) was equivalent to that of the final Biological Oxygen Demand, when the matters had been observed to be oxidized over a certain period, as shown in the graph of Figure 3 (Chapra, 2008).

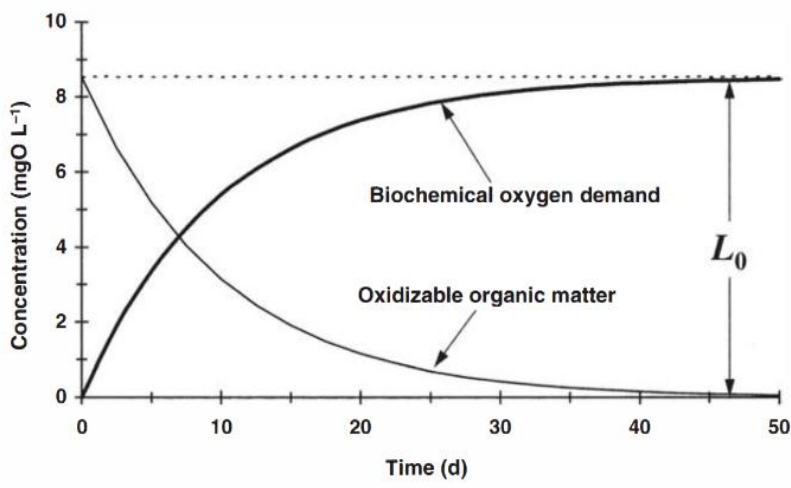

Figure 3. Relationship between BOD and organic matter.

The calculation formula for each pollutant load sector is presented as follows,

\subsubsection{Domestic settlement sector}

$P B P=\frac{\text { Total Population } \times F E \times R E \times \alpha}{1000}$

PBP indicated pollutant load potential for population settlement, and was expressed in $\mathrm{kg} /$ day. FE illustrated the emission factor, which produced the BOD value of $40 \mathrm{gr} /$ person/day, according to the research conducted by KLHK. $\mathrm{RE}$ also represented the city equivalent ratio, which produced urban, suburban, and hinterland values of $1,0.8125$, and 0.6250 , respectively. Also, $\alpha$ represented load transfer coefficient value, based on the distance from river. Additionally, 1000 was the conversion from gram to kilogram, based on the WASP requirement.

\subsubsection{Built-up land sector \\ $B P=$ land area $\times F E \times 1 \%$}

BP indicated pollutant load potential for built-up land use, expressed in $\mathrm{kg} /$ day. $\mathrm{FE}$ was the emission factor, which produced BOD values of $225,125,32.5,9.32$, and $15.34 \mathrm{~kg} / \mathrm{ha} /$ day, based on KLHK research for various land use, such as rice \& crop fields, plantations, forestry, etc, respectively. Also, was the amount of pollutant entering into river body.

\subsubsection{Livestock sector \\ $P B T=\frac{\text { Number of Livestock } \times F E \times 20 \%}{1000}$}

PBT indicated the pollutant load potential for livestock, expressed in $\mathrm{kg} /$ day. FE was the emission factor, which produced BOD values of 292, 207, 226, 128, 55.7, 34.1, 2.36, and 0.88 grams/ha/day, based on KLHK research for various livestocks, such as cow, buffalo, horse, pig, sheep, goat, chicken, and duck, respectively. Also, 20\% represented the amount of loads entering into river body, as 1000 was the conversion from gram to kilogram, based on the WASP requirement.

$$
\begin{aligned}
& 2.4 .4 \text { Hotel and Hospital } \\
& P B H=\frac{\text { Number of } \text { Room } \times F E}{1000} \\
& P B R S=\frac{\text { Number of Bed } \times F E}{1000}
\end{aligned}
$$

PBH \& PBRS were the pollutant load potentials for hotel \& hospital, expressed in $\mathrm{kg} / \mathrm{day}$. According to the Research and Development Centre of Ministry of Public Work, the BOD values for the emission factor of hotel and hospital were 55 and 123 gr/day, respectively.

$$
\begin{aligned}
& 2.4 .5 \text { Laundry } \\
& P B L=\frac{\text { Number of cloth } \times F E}{1000}
\end{aligned}
$$

$P B L$ was the pollutant load potential for laundry, and according to KLHK research, the emission factor was $0.3 \mathrm{gr} / \mathrm{kg}$ of clothes.

\subsection{Model Calibration and Validation}

The process of making a model via the use of WASP software, was carried out by using the trial-and-error approach, in order to produce a value close to the observation results. This approach was carried out by subtracting or adding the values of specific parameters, in order for the resulting outputs to be similar with the actual conditions. In this case, the pollutant load and the BOD were observed to be the concerned parameters, during simulation process. During the process of simulation, WASP was discovered 
to be monitoring and predicting the BOD, based on the input value of pollutant load in the input tab. Afterwards, a statistical test was needed, in order to determine the goodness that fits the Trial and Error results (Soewarno, 2014). One of the widely used test methods was the Chi-square method.

$X^{2}=\sum_{r=1}^{n} \frac{(\text { Obs value-Model value })^{2}}{\text { Model value }}$

The results of the calculation were compared to the $X^{2}$ value on the Chi-square table, with a $95 \%$ degree of confidence. Theoretically, a model is reported be accepted, when the results are smaller than the $X^{2}$ table, as well as rejected when they are greater. When the model is rejected, a recalibration process should be carried out until the results are close to the observed value. This process was conducted in order for the model to be accepted.

After the validation of the model, reliability test was carried out, in order to determine the accuracy in the measurement process. Also, the test was conducted in order to determine the reliability level of the model (Meeker and Escobar, 1998). The reliability test of the model was carried out using a statistical approach, through the method of relative bias $(\mathrm{rB})$ and Mean Relative Error (MRE).

$r B=\frac{\left(R_{m}-R_{o}\right)}{S_{o}}$ and $F=\frac{S_{m}^{2}}{S_{o}^{2}}$

where, $R_{m}$ = average value of model, $R_{o}=$ average value of observation, $S_{m}$ = standard deviation of model, and $S_{o}=$ standard deviation of observation. The model was accepted, when $-0.5<r B<0.5$ and $0.5<F<1.5$

Montgomery, 2012).

$R E=\frac{\mid \text { Model value }- \text { Obs value } \mid}{\text { Obs value }} \times 100 \%$

$M R E=\frac{1}{n} \sum R E$

Also, the mean relative error method stated that a model should be accepted, when the MRE value is $<10 \%$.

\subsection{WASP}

The WASP (Water Quality Analysis Simulation Program) model was originally developed by HydroScience in 1970, and had remained under the continuous development of the US-EPA. This model was created to help interpret and predict water quality responses to natural phenomena and manmade contamination, for various pollution management decisions. It is a dynamic, flexible, customizable simulation, which is used in analyzing various water bodies, such as ponds, rivers, lakes, reservoirs, estuaries, and coastal waters, based on the main principle of mass balance (Wool et al., 2020). This WASP model was also applied in some studies in Indonesia, such as those on the Ciujung (Hindriani et al., 2013) and Citarum Hilir (Laili and Sofyan, 2017) Rivers.

This model examined each part of the river segment, based on spatial and temporal input. It also predicted the amount of pollutant load, in consideration of the corresponding BOD Parameter. The existing condition of these BOD Parameters were obtained from the monitoring result of the Environmental Agency of Samarinda City. However, the TMDL condition was based on Government Regulation for class II river, which was $3 \mathrm{mg} / \mathrm{l}$. Therefore, the result of the WASP pollutant load prediction, was used to calculate the allocation of each segment.

\section{RESULTS AND DISCUSSION}

\subsection{River Geometry and Morphology}

Based on field observation concerning the dimension of the Karang Mumus Sub-watershed, the river was narrow and in the upstream \& downstream parts of the estuary, respectively. Moreover, the water flow was observed to be quite calm and slow. Also, almost all the slope levels were quite gentle, as the river had several turns, with the bed dominated by muddy soil.

Based on the initial research plan, the river was divided into five segments $(1,2,3,4,5)$. Segment 1 was a downstream area, which was close to the mouth of the Karang Mumus River, where most of the community worked as traders. Segment 2 
was the city centre and offices, with 3 being dominated by modern residential complexes. Also, segment 4 was the rural area for traditional communities, with 5 being the agricultural and plantation regions. According to cross-sectional analysis, the total length of the river was approximately $16.6 \mathrm{~km}$, where the distance was calculated based on the stakes made during the revitalization project by the local government.

Furthermore, the river dimensions were presented in Table 2, where the length of each segment was not uniform, depending on the geographical location and dominant activities that occurred in each area. The purpose of these segmentations was to accommodate the pollutant load analysis and calculation process. The parameter of the river dimension was also very important for the WASP simulation, as it became the input data in the channel geometry information section, which helped the model in measuring and predicting the size and capacity of the river.

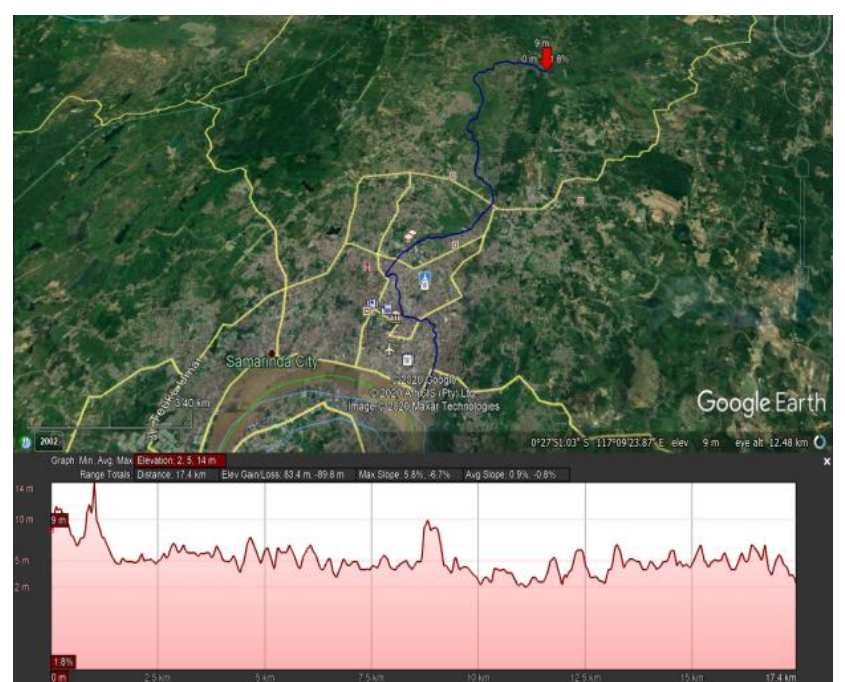

Figure 4. The Karang Mumus Sub-watershed from Google Earth satellite imagery.

\subsection{Pollutant Load Inventory and Identification}

The process of obtaining data to complete the pollutant load statistic was carried out with several channels, including secondary information surveys. This was in the form of a publication document, which was published by the Central Bureau of Statistics (BPS) 2019, to each sub-district levels in the Karang Mumus River, Samarinda city. Afterwards, the discharge data were obtained by calculation, via the use of the popular Manning formula of uniform flow, as an approach in steady condition of the river. This data was then compared with that of the River Basin Organization (BWS) III Kalimantan, as well as the results of several previous research (Lestari et al., 2019) on the Karang Mumus Subwatershed.

The results of the analysis and calculation of pollutant loads for each segment and sector, were summarized in Table 4 . Based on the pollutant load estimation formula, the calculation for each waste source was carried out by using the equation described in Section 2.4. According to the results of pollutant load inventory presented in Table 4, it was observed that Segment 2 had the highest percentage,(39\%) with BOD value of $4,606.92 \mathrm{~kg} /$ day. Moreover, this was accompanied by Segment 1 (29\%), which had a BOD value of 3,460.08 kg/day. Based on these results, both segments ( 1 \& 2) were categorized as urban areas, with a very busy level of socio-economic activity.

Besides that, the population densities in these areas were quite high, therefore, generating a significant number of wastes. However, segment 5 was at third place $(2,376.57 \mathrm{~kg} /$ day $)$, with sector 3 and 4 being the least at $7 \%$ and 5\%, respectively.

\begin{tabular}{lll}
\multicolumn{3}{l}{ Table 3. River Discharge } \\
\hline Segment & Flow $(\mathrm{m} / \mathrm{s})$ & Debit $\left(\mathrm{m}^{3} / \mathrm{s}\right)$ \\
\hline 1 & 1.08 & 139.92 \\
2 & 1.89 & 114.78 \\
3 & 1.54 & 75.35 \\
4 & 0.34 & 4.98 \\
5 & 0.68 & 14.15 \\
\hline
\end{tabular}


Table 2. Geometry of the Karang Mumus Sub-watershed

\begin{tabular}{|c|c|c|c|c|c|}
\hline Segment & Type of Activities & Distance (m) & $\begin{array}{l}\text { Cumulative Distance } \\
(\mathrm{m})\end{array}$ & $\begin{array}{l}\text { Average Width } \\
(\mathrm{m})\end{array}$ & $\begin{array}{l}\text { Average Depth } \\
(\mathrm{m})\end{array}$ \\
\hline 1 & Commerce & $3,509.21$ & $3,509.21$ & 44.34 & 4.38 \\
\hline 2 & City Center/Offices & $1,047.18$ & $4,556.39$ & 30.84 & 3.41 \\
\hline 3 & Modern Housing & 958.82 & $5,515.21$ & 25.01 & 3.60 \\
\hline 4 & $\begin{array}{l}\text { Village/Traditional } \\
\text { Market }\end{array}$ & $4,810.96$ & $10,326.17$ & 23.99 & 3.29 \\
\hline 5 & Agriculture/Plantation & $6,337.86$ & $16,664.03$ & 14.22 & 3.01 \\
\hline
\end{tabular}

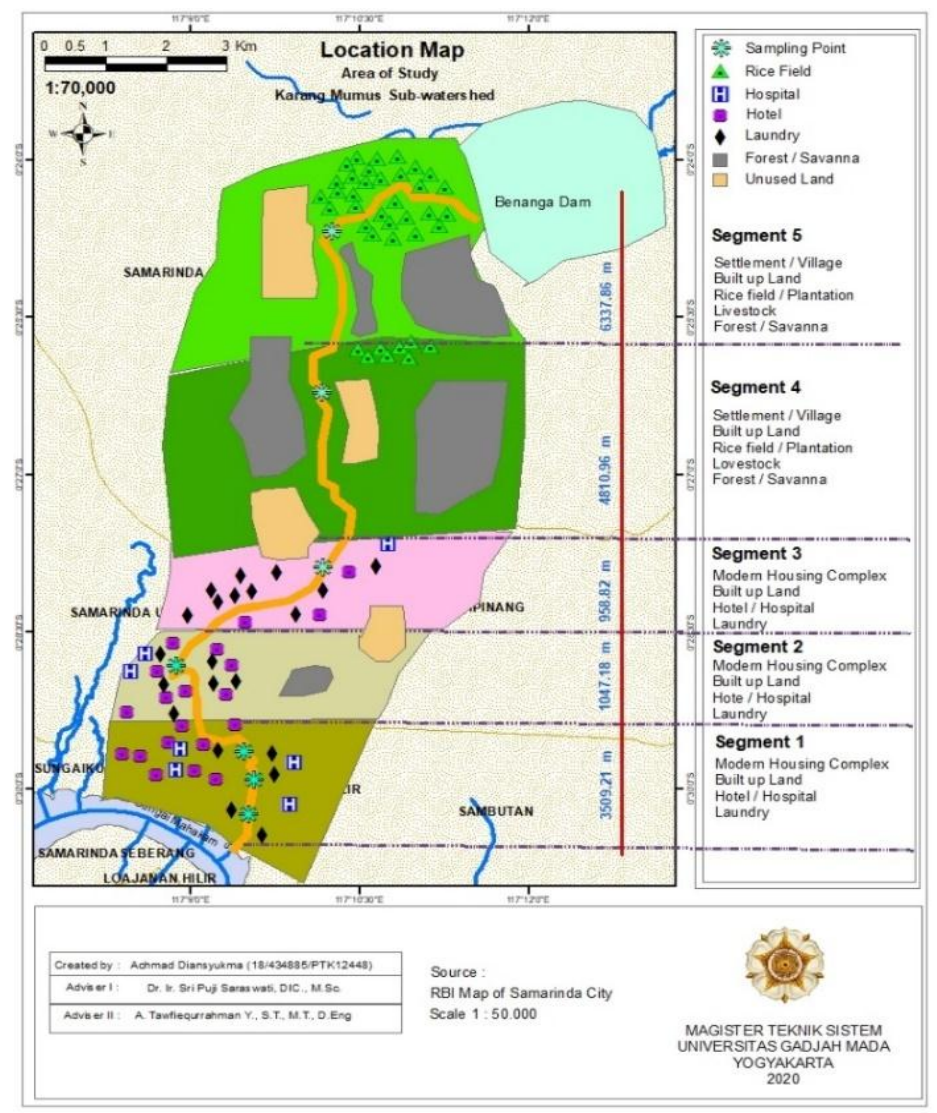

Figure 5. Distribution of Pollutant Loads.

Table 4. List of Pollutant Load Inventory (in kg/day)

\begin{tabular}{|c|c|c|c|c|c|c|}
\hline Source & Segment 1 & Segment 2 & Segment 3 & Segment 4 & Segment 5 & Total \\
\hline Domestics & $3,221.61$ & $4,324.49$ & 686.13 & 444.81 & 732.56 & $9,409.61$ \\
\hline Livestock & 28.69 & 13.44 & 12.71 & 59.17 & 422.10 & 536.11 \\
\hline Hotels & 62.70 & 35.97 & 6.38 & - & - & 105.05 \\
\hline Hospitals & 52.89 & 112.29 & 3.20 & - & - & 168.39 \\
\hline Laundry & 0.09 & 0.09 & 0.18 & - & - & 0.36 \\
\hline Built up Land & 91.56 & 119.05 & 132.96 & 132.96 & 158.81 & 635.32 \\
\hline Rice Fields & - & - & - & - & 448.24 & 448.24 \\
\hline Forests & 1.73 & 0.95 & 24.88 & 12.36 & 89.66 & 129.58 \\
\hline Plantations & .81 & 0.65 & 15.28 & 0.81 & 525.21 & 542.76 \\
\hline Total & $3,460.08$ & $4,606.92$ & 881.71 & 650.11 & $2,376.57$ & $11,975.40$ \\
\hline
\end{tabular}


Based on the pollutant load sectors in Table 4, it was also observed that "DOMESTICS" was the most dominating source, with the total value of $9409.61 \mathrm{~kg} /$ day (79\%). Also, the domestic pollutant load sector dominantly occurred in all segments. Segments 1-4 were observed to have a significant relationship, while 5 had a slightly balanced composition. In Segment 5, the pollutant loads produced from the livestock sector increased, due to the development in the number of cows, buffalos, goats, sheep, pigs, and chickens (Juwana and Nugroho, 2020). The pollutant loads generated by plantation and rice field also increased in Segment 5, due to the local government declaring it to be a dedicated area for agricultural development.

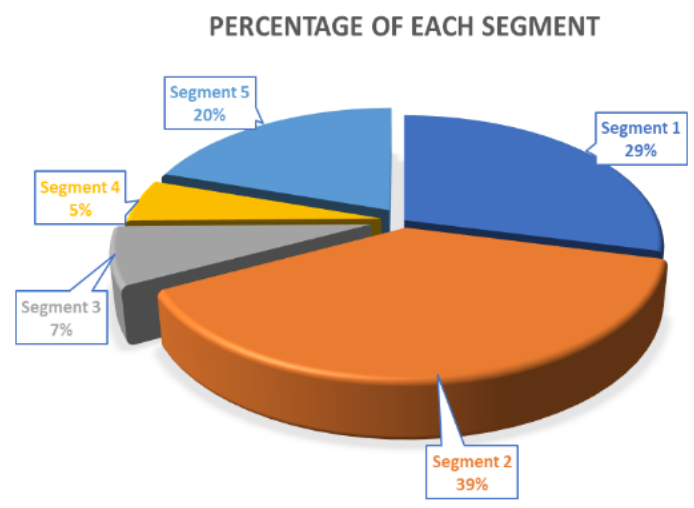

Figure 6. Chart of Pollutant Distribution Percentage.

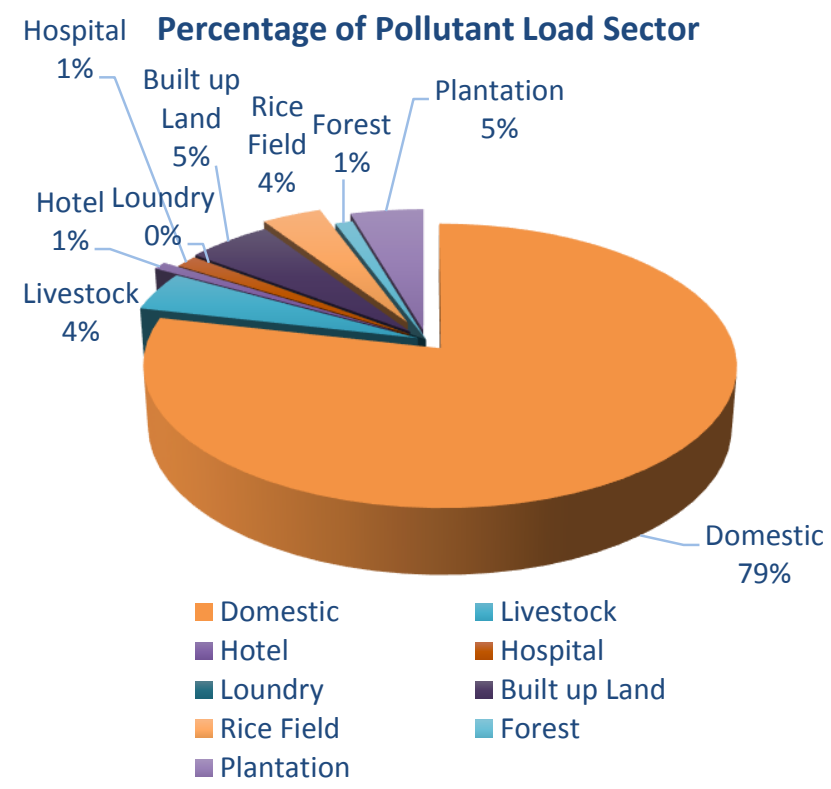

Figure 7. Chart of Pollutant Loads by Sector

\subsection{Modeling of Pollutant Load Capacity}

The use of the WASP software in the modeling of Pollutant Load Capacity of a river, has 3 main requirements as simulation inputs, namely morphology, flowrate, and water quality data. Also, the model simulation process was conducted by a trial-and-error method, in order to get a value close to the original state. Before simulating the pollutant loads through the use of BOD as a parameter, it was mandatory to perform the calibration of water discharge, which involved the input of data into the WASP. Based on the morphology and the flowrate, the discharge along the river reportedly fluctuated. The results of the discharge calibration were presented in Figure 8

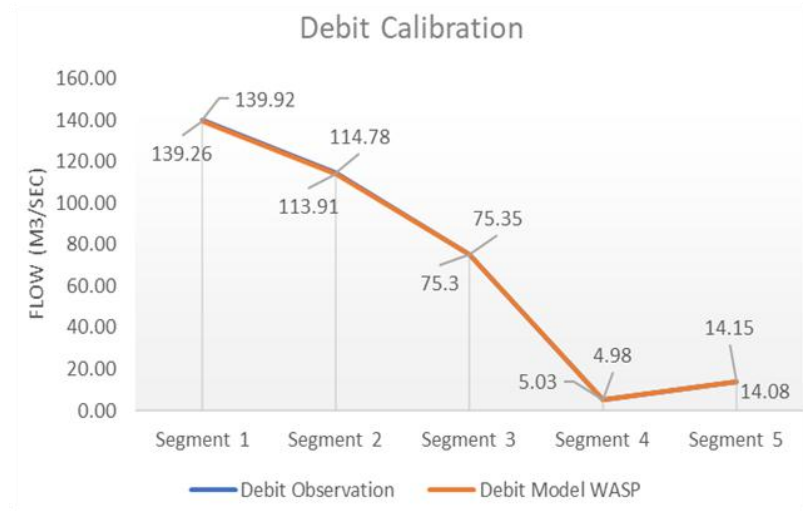

Figure 8. Chart of Discharge Calibration Results.

After the flowrate calibration was declared correct, the BOD simulation was then carried out. However, the result of the BOD simulation depended on the pollutant loads that are entering each segment. Since the factual database of pollutant loads entering each segment was also not accurately and adequately available yet, the use of modeling was needed. This modeling process was to be conducted, in order to determine the incoming pollutant loads, by monitoring the response to the water quality analysis result. The BOD value was obtained by the trial-and-error pollutant load, which was from the inventory result in the input functions. This value was then calibrated against the BOD laboratory test result, which had been gathered from the Environmental Agency of Samarinda. The trial-and-error was carried out repetitively, 
until the value per simulation target was obtained. For example, in segment 1, the BOD observation value as per BLH data was $1.81 \mathrm{mg} / \mathrm{l}$, which was the target to be achieved when operating the WASP. Furthermore, after inputting specific values in the load tab function with the commencement of the simulation, WASP was observed to predict the BOD based on the input value. When WASP predicts a lower or higher BOD value than the target, the simulation process should be repeated. This process should be continued, until the model predicts the BOD value close or accurate to the target. The point of simulation was the same as that of sampling in one segment, where the pollutant load penetration was assumed to have entered into the river body.

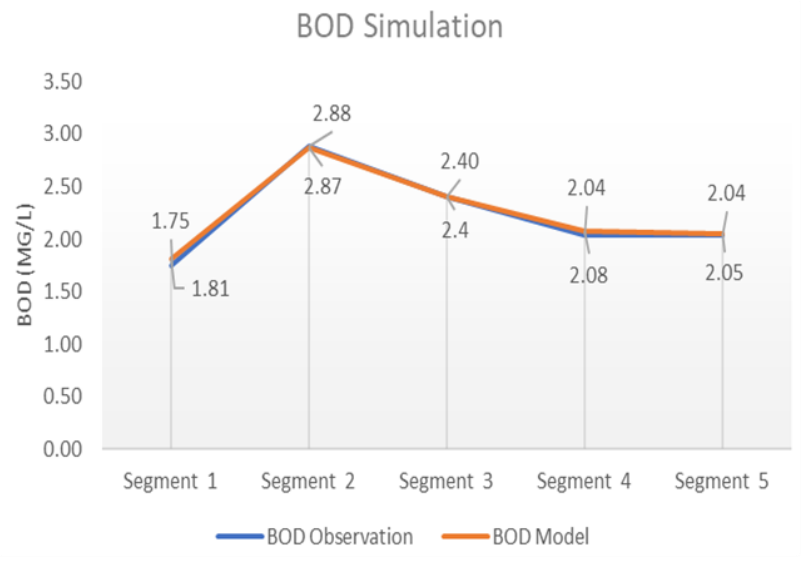

Figure 9. Chart of BOD Simulation Results.

Based on the calculation for the MRE method, the total Mean Relative Error value was $1.25 \%$, which was still below the required maximum of $10 \%$. Therefore, it was concluded that the model had been accepted through testing, via the use of the $\mathrm{rB}$ and MRE methods.

According to the next stage, after the BOD value was calibrated, a simulation to determine the existing pollutant loads was performed. The initial input for the pollutant loads ( $\mathrm{kg} / \mathrm{day}$ ) was carried out by inputting the results of the quantity inventory into each segment. Afterwards, the amounts of pollutant loads were changed randomly by a trial-and-error approach, until target results were obtained, as presented in Table 6.

Table 6. Difference in Pollutant Loads in Inventory and Existing Analyses (in kg/day)

\begin{tabular}{lrr}
\hline \multicolumn{1}{c}{ Segment } & Load Inventory & Load Existing \\
\hline 1 & $3,460.08$ & 355 \\
2 & $4,606.92$ & 695 \\
3 & 881.71 & 465 \\
4 & 650.11 & 75 \\
5 & $2,376.57$ & 2,015 \\
\hline Total & $11,975.40$ & 3,605 \\
\hline
\end{tabular}

The calculation of pollutant load carrying capacity was based on a predetermined quality standard value. According to the Government Regulation of East Kalimantan Number 02/2011, it was stated that Karang Mumus River, (from upstream to downstream) was categorized as a class 2 water body, which should be used for water recreation infrastructures/facilities, freshwater cultivation, livestock feeding, rice field irrigation, and/or other uses. Also, the BOD Quality Standard for class 2 was $3 \mathrm{mg} /$. Moreover, the simulation of pollutant load carrying capacity was also carried out by the trial-and-error method, in order to obtain BOD concentration values, which were close to those of the Quality standard.

Furthermore, the result of the model summarized in Table 7 showed that the entire river in the area of study, still had the ability to accept pollutant loads within the BOD Quality Standard limit of $3 \mathrm{mg} / \mathrm{l}$, for each segment. The carrying capacity of the river pollution from upstream to downstream was $5,670 \mathrm{~kg} /$ day, with the existing load at $3,605 \mathrm{~kg} /$ day. However, the river still had the ability to accept pollutant loads of $2,065 \mathrm{~kg} / \mathrm{day}$, based on the BOD parameter. 
Table 5. Calculation of Validation and Reliability Tests

\begin{tabular}{|c|c|c|c|c|c|c|c|c|}
\hline BOD Obs & BOD Model & $X^{2}$ Calc & $x_{i}-\mu \mathrm{Obs}$ & $x_{i}-\mu$ Model & $\left(x_{i}-\mu\right)^{2}$ Obs & $\left(x_{i}-\mu\right)^{2}$ Model & RE (\%) & MRE (\%) \\
\hline 1.75 & 1.81 & 0.001989 & -0.472 & -0.432 & 0.223 & 0.187 & 3.43 & 0.69 \\
\hline 2.88 & 2.87 & 0.000035 & 0.658 & 0.658 & 0.433 & 0.394 & 0.35 & 0.07 \\
\hline 2.40 & 2.40 & 0.000000 & 0.178 & 0.158 & 0.032 & 0.025 & 0.00 & 0.00 \\
\hline 2.04 & 2.08 & 0.000769 & -0.182 & -0.162 & 0.033 & 0.026 & 1.96 & 0.39 \\
\hline 2.04 & 2.05 & 0.000049 & -0.182 & -0.192 & 0.033 & 0.037 & 0.49 & 0.10 \\
\hline \multicolumn{2}{|c|}{$X^{2}$ Calculation } & 0.002842 & \multicolumn{3}{|c|}{$r R=\underline{(2.242-2.222)}$} & 0.052 & Total RE & 6.23 \\
\hline \multicolumn{2}{|c|}{ Degree of Freedom } & 0.95 & \multicolumn{3}{|c|}{$r B=\frac{0.388}{2}$} & & & \\
\hline \multicolumn{2}{|c|}{ Number of Data } & 5 & \multirow{2}{*}{\multicolumn{3}{|c|}{$F=\frac{(0.366)^{2}}{(0.388)^{2}}$}} & 0.888 & MRE Total & 1.25 \\
\hline \multicolumn{2}{|c|}{$X^{2}$ Chi-square Table } & 1.145 & & & & & & \\
\hline \multicolumn{2}{|c|}{$X^{2}$ Calc. $<X^{2}$ Table } & Accepted & \multicolumn{2}{|c|}{$-0.5<r B<0.5 \& 0.5$} & $<F<1.5$ & Accepted & $\mathrm{MRE}<10$ & Accepted \\
\hline
\end{tabular}

Table 7. The BOD Pollutant Load-Carrying Capacity Simulation Results

\begin{tabular}{|c|c|c|c|c|c|c|c|}
\hline Segment & $\begin{array}{l}\text { Distance } \\
(\mathrm{m})\end{array}$ & $\begin{array}{l}\text { Debit } \\
\left(\mathrm{m}^{3} / \mathrm{s}\right)\end{array}$ & $\begin{array}{l}\mathrm{BOD} \\
(\mathrm{mg} / \mathrm{l})\end{array}$ & $\begin{array}{l}\text { Existing } \\
\text { Load } \\
\text { (kg/day) }\end{array}$ & $\begin{array}{l}\text { TMDLs } \\
\text { (kg/day) }\end{array}$ & $\begin{array}{l}\text { Margin } \\
\text { (kg/day) }\end{array}$ & Remark \\
\hline 1 & $3,509.21$ & 139.92 & 1.81 & 355 & 2,095 & 1,740 & $\begin{array}{l}\text { Still has the ability to receive } \\
\text { pollutant load }\end{array}$ \\
\hline 2 & $1,047.18$ & 114.78 & 2.87 & 695 & 305 & -390 & $\begin{array}{l}\text { Pollutant load should be } \\
\text { reduced by } 56 \%\end{array}$ \\
\hline 3 & 958.82 & 75.35 & 2.40 & 465 & 245 & -220 & $\begin{array}{l}\text { Pollutant load should be } \\
\text { reduced by } 47 \%\end{array}$ \\
\hline 4 & $4,810.96$ & 4.98 & 2.08 & 75 & 65 & -10 & $\begin{array}{l}\text { Pollutant load should be } \\
\text { reduced by } 13 \%\end{array}$ \\
\hline \multirow[t]{2}{*}{5} & $6,337.86$ & 14.15 & 2.05 & 2,015 & 2,960 & 945 & $\begin{array}{l}\text { Still has the ability to receive } \\
\text { pollutant load }\end{array}$ \\
\hline & Total & & & 3,605 & 5,670 & 2,065 & \\
\hline
\end{tabular}

\subsection{Pollutant Load Allocation}

The allocation of the margin capacity for adding pollutant loads was different in each source sector (Liang et al., 2015). The additional margin did not apply to all segments, as there were some (segments 2, 3, \& 4) that needed to reduce the pollutant loads. Based on the comparisons with previous studies that had conducted analysis at the same location with QUAL2Kw method, the result was observed to be exceeded for all segments (Lestari et al., 2019). In this research, the BOD data were officially obtained from BLH Samarinda City, as a result of monitoring. However, for TMDL, the reference BOD was set up based on the standard quality for river class
II, which was $3 \mathrm{mg} / \mathrm{l}$. When running simulation, WASP monitored and predicted the whole segments of the river, with the consideration of related factors, such as morphology, dimension, flow discharge, purification process, etc. Therefore, it was understood that segment 2, 3, and 4 exceeded the TMDL, due to the pollutant load carry-over from previous segment. Also this was due to the incomplete self-purification process, which reportedly affected the downstream segment. The allocation of additional load margin in each sector was also based on the percentage of pollutants at the time of the inventory, as summarized in Table 4 . 
Table 8. Pollutant Load Allocation per Sector (in kg/day)

\begin{tabular}{llll}
\hline Sector & $\begin{array}{l}\text { Existing } \\
\text { Load }\end{array}$ & TMDLs & $\begin{array}{l}\text { Additional } \\
\text { Margin }\end{array}$ \\
\hline Domestic & $2,832.67$ & $4,455.26$ & $1,622.59$ \\
Livestock & 161.39 & 253.84 & 92.45 \\
Hotel & 31.62 & 49.74 & 18.11 \\
Hospital & 50.69 & 79.73 & 29.04 \\
Laundry & 0.03 & 0.04 & 0.02 \\
Built-up Land & 191.26 & 300.82 & 109.56 \\
Rice Field & 134.94 & 212.23 & 77.29 \\
Forest/Savanna & 39.01 & 61.35 & 22.34 \\
Plantation & 163.39 & 256.99 & 93.59 \\
\hline Total & 3,605 & 5,670 & 2,065 \\
\hline
\end{tabular}

Table 8. Pollutant Load Allocation for Segment 1 (in kg/day)

\begin{tabular}{lrrr}
\hline Sector & $\begin{array}{c}\text { Existing } \\
\text { Load }\end{array}$ & \multicolumn{1}{c}{ TMDL } & $\begin{array}{c}\text { Additional } \\
\text { Margin }\end{array}$ \\
\hline Domestic & 330.53 & $1,950.53$ & $1,620.08$ \\
Livestock & 2.94 & 17.37 & 14.43 \\
Hotel & 6.43 & 37.96 & 31.53 \\
Hospital & 5.43 & 32.02 & 26.60 \\
Laundry & 0.01 & 0.05 & 0.05 \\
Built-up Land & 9.39 & 55.44 & 46.04 \\
Rice Field & 0 & 0 & 0 \\
Forest/Savanna & 0.18 & 1.05 & 0.87 \\
Plantation & 0.08 & 0.49 & 0.41 \\
\hline Total & 355 & 2,095 & 1,740 \\
\hline
\end{tabular}

Table 8. Pollutant Load Allocation for Segment 2 (in kg/day)

\begin{tabular}{llll}
\hline Sector & $\begin{array}{l}\text { Existing } \\
\text { Load }\end{array}$ & TMDLs & $\begin{array}{l}\text { Reduction } \\
\text { Margin }\end{array}$ \\
\hline Domestic & 652.40 & 286.31 & 366.10 \\
Livestock & 2.03 & 0.89 & 1.14 \\
Hotel & 5.43 & 2.38 & 3.05 \\
Hospital & 16.94 & 7.43 & 9.51 \\
Laundry & 0.01 & 0.01 & 0.01 \\
Built up Land & 17.96 & 7.88 & 10.08 \\
Rice Field & 0 & 0 & 0 \\
Forest/Savanna & 0.14 & 0.06 & 0.08 \\
Plantation & 0.10 & 0.04 & 0.06 \\
\hline Total & 695 & 305 & 390 \\
\hline
\end{tabular}

Table 10. Pollutant Load Allocation for Segment 3 (in kg/day)

\begin{tabular}{llll}
\hline Sector & $\begin{array}{l}\text { Existing } \\
\text { Load }\end{array}$ & TMDL & $\begin{array}{l}\text { Reduction } \\
\text { Margin }\end{array}$ \\
\hline Domestic & 361.92 & 190.69 & 171.23 \\
Livestock & 6.70 & 3.53 & 3.17 \\
Hotel & 3.37 & 1.77 & 1.59 \\
Hospital & 1.69 & 0.89 & 0.80 \\
Laundry & 0.10 & 0.05 & 0.05 \\
Built-up Land & 70.13 & 36.95 & 33.18 \\
Rice Field & 0 & 0 & 0 \\
Forest/Savanna & 13.12 & 6.91 & 6.21 \\
Plantation & 8.06 & 4.25 & 3.81 \\
\hline Total & 465 & 245 & 220 \\
\hline
\end{tabular}

Table 11. Pollutant Load Allocation for Segment 4 (in kg/day)

\begin{tabular}{llll}
\hline Sector & $\begin{array}{l}\text { Existing } \\
\text { Load }\end{array}$ & TMDLs & $\begin{array}{l}\text { Reduction } \\
\text { Margin }\end{array}$ \\
\hline Domestic & 51.32 & 44.47 & 6.84 \\
Livestock & 6.83 & 5.92 & 0.91 \\
Hotel & 0 & 0 & 0 \\
Hospital & 0 & 0 & 0 \\
Laundry & 0 & 0 & 0 \\
Built-up Land & 15.34 & 13.29 & 2.05 \\
Rice Field & 0 & 0 & 0 \\
Forest/Savanna & 1.43 & 1.24 & 0.19 \\
Plantation & 0.09 & 0.08 & 0.01 \\
\hline Total & 75 & 65 & 10 \\
\hline
\end{tabular}

Table 12. Pollutant Load Allocation for Segment 5 (in kg/day)

\begin{tabular}{llll}
\hline Sector & $\begin{array}{l}\text { Existing } \\
\text { Load }\end{array}$ & TMDL & $\begin{array}{l}\text { Additional } \\
\text { Margin }\end{array}$ \\
\hline Domestic & 621.11 & 912.39 & 291.29 \\
Livestock & 357.88 & 525.72 & 167.84 \\
Hotel & 0 & 0 & 0 \\
Hospital & 0 & 0 & 0 \\
Laundry & 0 & 0 & 0 \\
Built-up Land & 134.65 & 197.80 & 63.15 \\
Rice Field & 380.04 & 558.28 & 178.23 \\
Forest/Savanna & 76.02 & 111.67 & 35.65 \\
Plantation & 445.30 & 654.14 & 208.84 \\
\hline Total & 2,015 & 2,960 & 945 \\
\hline
\end{tabular}

\section{CONCLUSION}

Based on the calculation of pollutant loadcarrying capacity using BOD as a parameter, the total segments of the Karang Mumus Subwatershed still received more loads, compared to the existing conditions. However, the allocation of pollutant loads for each segment varied, as segments 1 and 5 still had an additional margin. According to the defined river class, segments 2, 3 , and 4 reduced the pollutant load, in order to meet the BOD quality standards. The results of this study should be a consideration for the local government, in order to encourage the development of Samarinda City to the northern area, as well as alleviate the pollutants in the downtown region. The results should also be a reference in revitalizing Karang Mumus Subwatershed, in order to restore the river to its original conditions.

\section{DISCLAIMER}

The authors declare no conflict of interest. 


\section{AVAILABILITY OF DATA AND MATERIALS}

All data are available from the author

\section{ACKNOWLEDGMENTS}

The authors are grateful to the Environmental Agency of Samarinda and River Basin Institution of Kalimantan III, for providing the data needed for this research.

\section{REFERENCES}

Abdi, Z., Hadi, M. P. and Widiyastuti, M., 2011. 'Kajian Daya Tampung Beban Pencemaran Sungai Batanghari Pada Penggal Gasiang Sungai Langkok Sumatera Barat', Majalah Geografi Indonesia, 25(1), pp. 70-94. Available at: https://doi.org/10.22146/mgi.13366.

Asdak, C., 2010. Hidrologi dan Pengelolaan Daerah Aliran Sungai. 5th edn. Yogyakarta: Gadjah Mada University Press.

BPS, 2019. Kota Samarinda Dalam Angka 2019. Samarinda: BPS Kota Samarinda.

C Montgomery, D., 2012. Design and Analysis of Experiments. New York: Jhon Wiley and Sons.

Chapra, S. C., 2008. Surface water-quality modeling. Long Grove, Illinois: Waveland press.

Djoharam, V., Riani, E. and Yani, M., 2018. 'Analisis Kualitas Air Dan Daya Tampung Beban Pencemaran Sungai Pesanggrahan Di Wilayah Provinsi DKI JAKARTA', Jurnal Pengelolaan Sumberdaya Alam dan Lingkungan (Journal of Natural Resources and Environmental Management), 8(1), pp. 127-133. doi: 10.29244/jpsl.8.1.127-133.

Flotemersch, J. E. et al., 2015. 'A Watershed Integrity Definition and Assessment Approach to Support Strategic Management of Watersheds', River Research and Applications. doi: 10.1002/rra.2978.

Hindriani, H. et al., 2013. 'Identifikasi daya tampung beban pencemaran sungai ciujung dengan model wasp dan strategi pengendaliannya', Jurnal Bumi Lestari, 13(2), pp. 275-287.
Iskandar, I., 2007. 'Panduan Pelatihan Pengelolaan Kualitas Air', Jakarta: Puslitbang Sumberdaya Air Kementerian Pekerjaan Umum.(in bahasa Indonesia).

Juwana, I. and Nugroho, D. P., 2020. 'Calculation of Pollutant Load in Cipunagara River: Livestock Sector', Journal of the Civil Engineering Forum. doi: $10.22146 /$ jcef.52675.

Laili, F. N. and Sofyan, A., 2017. 'Identifikasi Daya Tampung Beban Pencemaran Sungai Citarum Hilir Di Karawang Dengan WASP', Jurnal Tehnik Lingkungan, 23(1), pp. 1-12. doi: 10.5614/j.tl.2017.23.1.1.

Lestari, S. et al., 2019. 'Study of carrying capacity of Karang Mumus River using the QUAL2Kw Program', International Journal of Agriculture \& Environmental Science, 6(6), pp. 67-72. doi: 10.14445/23942568/ijaes-v6i6p110.

Liang, S. et al., 2015. 'A pollutant load hierarchical allocation method integrated in an environmental capacity management system for Zhushan Bay, Taihu Lake', Science of the Total Environment, 533, pp. 223-237. doi: 10.1016/j.scitotenv.2015.06.116.

Meeker, W. Q. and Escobar, L. A., 1998. Statistical Methods for Reliability Data. Canada: Wiley (Wiley Series in Probability and Statistics).

Pramaningsih, V., Suprayogi, S. and Setyawan Purnama, I. L., 2017. 'Kajian Persebaran Spasial Kualitas Air Sungai Karang Mumus, Samarinda, Kalimantan Timur', Jurnal Pengelolaan Sumberdaya Alam dan Lingkungan (Journal of Natural Resources and Environmental Management), 7(3), pp. 211-218. doi: 10.19081/jpsl.2017.7.3.211.

Saraswati, S. P. et al., 2019. 'Water Quality Index Performance for River Pollution Control Based on Better Ecological Point of View (A Case Study in Code, Winongo, Gadjah Wong Streams)', Journal of the Civil Engineering Forum, 5(1), pp. 47-56. doi: 10.22146/jcef.41165.

Soewarno, 2014. Aplikasi Metode Statistika Untuk 
Analisis Data Hidrologi. Yogyakarta: Graha Ilmu.

Triatmodjo, B., 2008. Hidrologi Terapan. Yogyakarta: Beta Offset.

Wardhana, W. A., 2004. 'Dampak Pencemaran Lingkungan (Edisi Revisi)', Yogyakarta: Penerbit Andi.

Wen, Y., Schoups, G. and Van De Giesen, N., 2017. Organic pollution of rivers: Combined threats of urbanization, livestock farming and global climate change, Scientific Reports. doi: 10.1038/srep43289.
Wijaya, D. S. and Juwana, I., 2018. 'Identification and Calculation of Pollutant Load in Ciwaringin Watershed, Indonesia: Domestic Sector', in IOP Conference Series: Materials Science and Engineering. doi: 10.1088/1757899X/288/1/012049.

Wool, T. et al., 2020. 'WASP 8: The next generation in the 50-year evolution of USEPA's water quality model', Water (Switzerland), 12(5), pp. 1-33. doi: 10.3390/W12051398. 
(This page is intentionally left blank) 